\title{
Sialic acid receptors: focus on their role in influenza infection
}

\author{
Guadalupe Ayora-Talavera \\ Virology Laboratory, Center of \\ Regional Research Dr Hideyo \\ Noguchi, Autonomous University of \\ Yucatan, Merida, Yucatan, Mexico
}

This article was published in the following Dove Press journal: Journal of Receptor, Ligand and Channel Research

\begin{abstract}
Receptor-binding specificity is a major determinant of host range, pathogenesis, and interspecies transmission in influenza virus. Recognition of different conformations of sialic acid by the influenza virus hemagglutinin has driven influenza intra- and interspecies transmission for nearly 100 years since the first human pandemic was recorded in 1918. Key amino acid residues near or at the receptor-binding site of the hemagglutinin of different influenza A subtypes correlate with the ability of the virus to infect and replicate in the upper or lower respiratory tract of the host and transmit efficiently. A global concern exists for those highly pathogenic avian viruses that have emerged with the potential to cause a novel pandemic in humans. Studying the receptor-binding affinity to sialic acid receptors as a marker of pandemic risk could provide reliable measures to aid in timely pandemic planning and surveillance worldwide.
\end{abstract}

Keywords: influenza A, sialic acid, receptor binding, host range

\section{Introduction}

The cell entry of influenza virus is governed by receptor biology. Sialic acids (SAs) of cell surface glycoproteins and glycolipids are the receptors for the influenza virus, recognized by the viral glycoprotein hemagglutinin (HA; Figure 1). The site on HA at which the cellular receptors are bound is at the distal end of the molecule. ${ }^{1,2}$ The receptor-binding site (RBS) is recognized as a pocket of highly conserved residues in all subtypes of influenza viruses; mutations in the RBS are required for adaptation of the animal viruses HA to the human host. ${ }^{3}$

Two major linkages between SA and the penultimate galactose residues of carbohydrate side chains are found in nature, Neu5Ac $\alpha(2,3)$-Gal and Neu5Ac $\alpha(2,6)-G a l .{ }^{4}$ Most avian and equine influenza viruses preferentially bind to SA joined to the sugar chain through an $\alpha 2-3$ linkage, and viruses isolated from birds possess HAs with high affinity for this type of sugar, whereas human influenza A viruses (IAV) preferentially use $\alpha 2-6$ linked SA as a cellular receptor. ${ }^{5}$

The affinity of the influenza virus HA for respective SA species is one of the factors that determine whether animal viruses can cross the host barrier. This event is facilitated when animal species such as swine or quail function as "mixing vessels", because they express both types of SA receptors. ${ }^{6,7}$

\section{Investigating the SA receptor-binding properties of IAV}

Influenza virus entry to susceptible cells is governed by the interaction between the HA surface antigen of the virus and the cell receptor SA. The recognition of different
Correspondence: Guadalupe Ayora-Talavera Investigaciones Regionales Dr Hideyo Noguchi, Universidad Autónoma de Yucatán, Unidad Inalambrica Calle 96 $\mathrm{S} / \mathrm{N} \times \mathrm{Av}$. Jacinto Canek y Calle 47 Paseo de las Fuentes, C.P. 97225, Mérida,

Yucatán, México

Tel +52 019999246412

Email talavera@correo.uady.mx
Journal of Receptor, Ligand and Channel Research 2018:10 I-II

(c) (i) (8) $\odot 2018$ Ayora-Talavera. This work is published and licensed by Dove Medical Press Limited. The full terms of this license are avalable at https://wwr.dovepress.com/terms

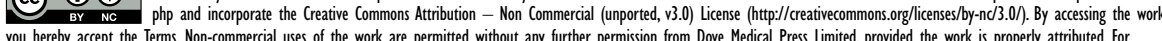
you hereby accept the Terms. Non-commercial uses of the work are permitted without any further permission from Dove Medical Press Limited, provided the work is properly attributed. For permision for commercial use of this work, please see paragraphs 4.2 and 5 of our Terms (https:/www.dovepress.com/terms.php). 


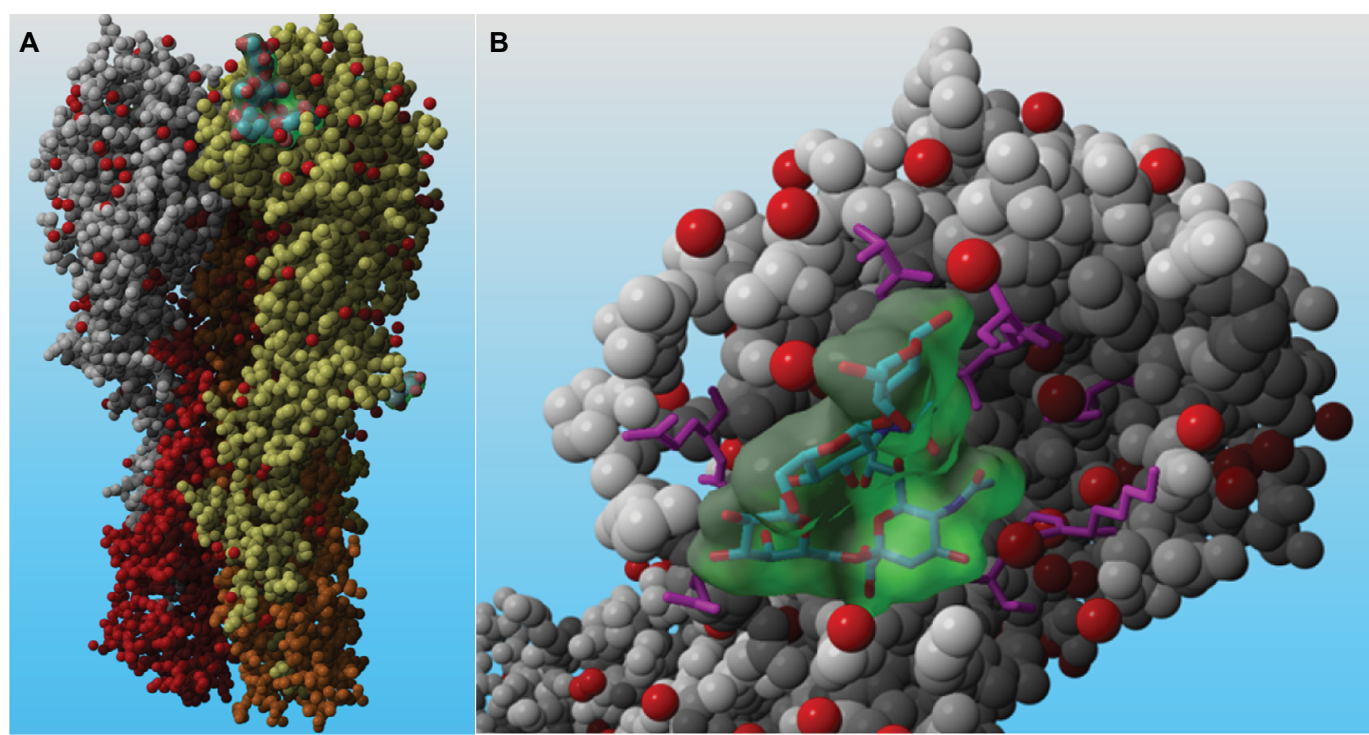

Figure I Influenza virus HA molecule from A/California/04/2009 (PDB: 3ube).

Notes: Each monomer in the $(\mathbf{A})$ trimer is indicated in color; the front view shows the HA, (green or gray) and $\mathrm{HA}_{2}$ subunits (red or orange). A closer view of the (B) globular head and the interaction with ligand LSTc; in purple are shown some of the amino acid residues at the RBS that directly interact with the sialic acid-like receptor. Images were generated with Yasara software version 17.1.28.

Abbreviations: HA, hemagglutinin; LSTc, sialylneolacto-N-tetraose c; RBS, receptor-binding site; PDB, Protein Data Bank.

types of SA linkages by human and animal viruses is a major barrier for host range restriction. Lessons learned from the old pandemics showed that viruses from 1918, 1957, and 1968 all acquired mutations at the HA RBS during the first months of the pandemic that allowed them to transmit between humans. ${ }^{8}$

A simple way to assess the receptor specificity of influenza viruses can be through the agglutination of erythrocytes from different animal species. Human viruses agglutinate erythrocytes from chicken, ducks, guinea pigs, and sheep, but not those from horses or cows; however, avian and equine viruses agglutinate all these erythrocytes. ${ }^{9}$

"Hemagglutination assays" (Figure 2A) have been widely used in routine diagnostics since they were first described by Hirst in 1941. The property of the influenza virus HA to agglutinate red blood cells (RBCs) from different species reflects diversity in SA species. However, virus evolution and host adaptation affect the recognition of SA species, and the HA assay can be poorly specific and even unreliable for certain strains.

For many years, the interaction of the influenza virus HA with the SA receptor was modeled with trisaccharide or pentasaccharide molecules (e.g., Neu5Ac- $\alpha 2,3 / \alpha-2,6 \mathrm{Gal} \beta 1-4 \mathrm{Glc}$ ), where the SA is at the end of the oligosaccharide chain (Figure $2 \mathrm{~B}) .{ }^{10}$ The interaction between HAs from human viruses and the receptor analogs varies with subtype. H1 HAs were bound strongly to sialylneolacto- $N$-tetraose c and $6^{\prime}$-sialyl$\mathrm{N}$-acetyllactosamine than to $6^{\prime}$-sialyllactose trisaccharide or $3^{\prime}$-sialyllactose trisaccharide, suggesting an interaction with the asialo portions of the long analogs, whereas H3 HAs were bound equally strong to $6^{\prime}$-sialyllactose trisaccharide or $6^{\prime}$-sialyl- $N$-acetyllactosamine. ${ }^{11,12}$ Otherwise, the glycans preferred by the avian HA could vary depending on the avian species from which the virus was isolated.

The "glycan array" technology has become a powerful technology to study the binding profile of human and animal glycoproteins (Figure 2C). Numerous plant lectins, glycan-specific antibodies, and microbial toxins used in research have been analyzed for their specificity on glycan arrays. Glycan microarrays are also capable of detecting carbohydrate-specific antibodies in human sera, or the binding of bacteria and eukaryotic cells. ${ }^{13}$ In recent years, massive improvements in glycobiology knowledge and the availability of new technology and resources have shown that influenza viruses recognize different forms of glycopolymers with terminal SA. ${ }^{14,15}$

Glycan arrays present many different receptor mimics and may contain a more biologically relevant molecule. The extent to which influenza HA proteins discriminate between these different carbohydrates is perhaps surprising. The glycan array analysis is a novel and suitable technique to analyze subtle differences in carbohydrate receptor specificities of known and pandemic human influenza strains as the novel H1N1pdm09 subtype. ${ }^{16}$ The glycan array format has been used to compare the binding profiles between the pH1N1 virus and the human seasonal H1N1, H3N2, and the avian origin $\mathrm{H} 5 \mathrm{~N} 1, \mathrm{H} 7 \mathrm{~N} 7$, or the $\mathrm{H} 9 \mathrm{~N} 2 .{ }^{15}$ 


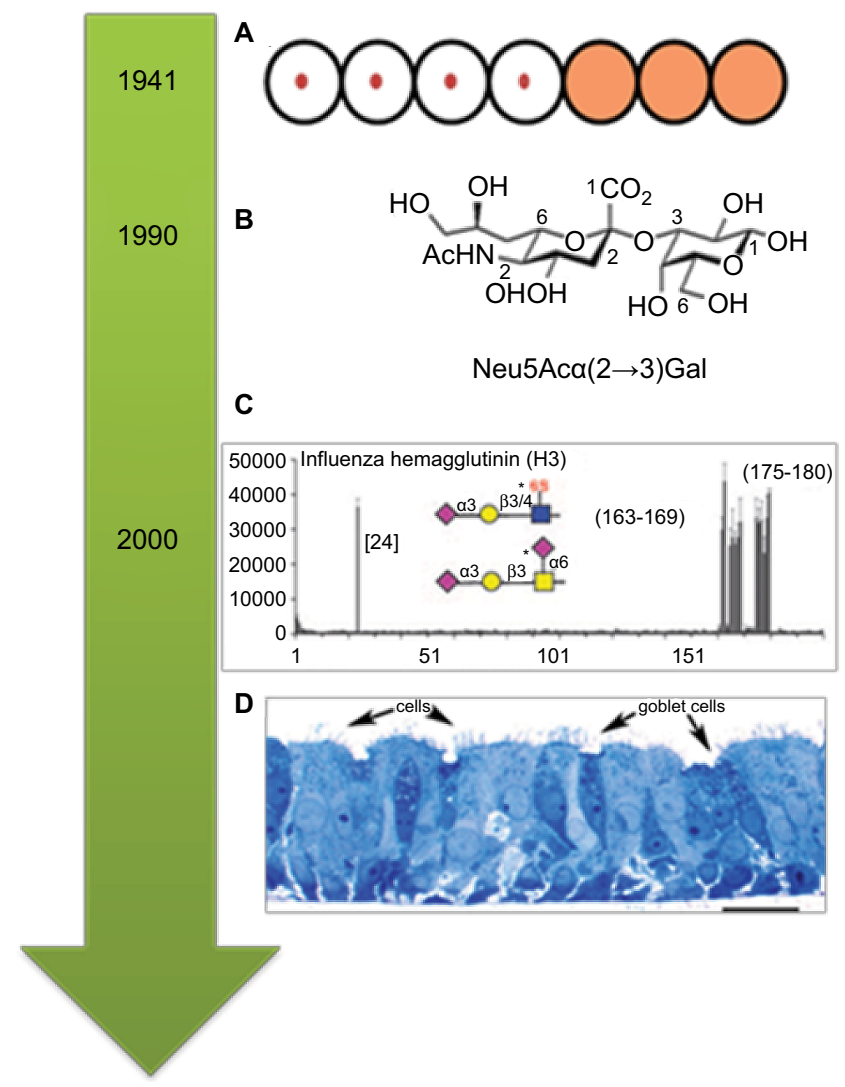

Hemagglutination assay using red blood cells of different species. Used until nowadays

Development of synthetic sialylgly copolymers containing three to five saccharides. Tested in a solid-phase enzyme-linked assay

Development of synthetic sialylgly copolymers containing sulfated and fucosylated intermediate chains

Development of printed covalent glycan array for ligand profiling

Development of airway cultured in vitro systems for celltype binding recognition

Figure 2 Schematic representation of the methods and techniques used throughout influenza virus history to identify the receptor type recognition.

"Cultured human airway cells and excided human trachea sections" have been used for studying the preferred cell type of infection by the influenza virus (Figure 2D). Human influenza virus infects the upper respiratory tract with major involvement of the pharynx and trachea. Human viruses need to access their target cells as well as to overcome the presence of mucins, which are produced by the goblet cells and are abundantly expressed in trachea. ${ }^{17}$ Several groups have shown that cultures of fully differentiated human airway epithelia or human tracheobronchial epithelia are readily infected with influenza viruses, although the cell tropism differs between viruses of avian and human origin in these systems. ${ }^{17-19}$ Accordingly, lectin staining of the cultures showed that some, but not all, ciliated cells expressed SA $\alpha 2,3$, whereas non-ciliated cells expressed only $\mathrm{SA} \alpha 2,6$. Antigen detection confirmed that only ciliated cells were infected with avian influenza viruses (AIV), whereas nonciliated cells were infected with human viruses. Although avian viruses replicated, a restricted spread to adjacent cells was observed, because not all ciliated cells expressed the avian type of receptor, suggesting restrictions to adaptation by a reduced cellular tropism.

\section{Receptor-binding profile of influenza HINI: from Spanish flu to HIN I pdm09}

The IAV H1N1 subtype has co-circulated in humans together with the H3 subtype since 1977, and both have adapted for human replication and transmission during decades of being human pathogens..$^{20,21}$

For the H1 HA, it is clear that mutations in amino acids 190 and 225 (hereafter considered in $\mathrm{H} 3$ numbering) were essential for the adaptation of avian origin $\mathrm{H} 1 \mathrm{~N} 1$ viruses to replicate and transmit either in swine or in humans. Receptorbinding analysis of the HA variants demonstrated that the 1918 virus with the combination D190 and G225 was bound to both $\mathrm{SA} \alpha 2,3$ and $\mathrm{SA} \alpha 2,6$ molecules, whereas the variant with D190 and D225 behaved like typical human viruses and showed preference for SA 2,6. A mutated 1918 virus with the combination E190 and G225 (avian-like genotype) 
showed preference for the avian type of receptor SA $\alpha 2,3$. $^{15,22}$ Complementary studies using the preferred animal ferret model suggested that amino acid changes at conserved residues 190 and 225 affected not only the receptor-binding phenotype of the $1918 \mathrm{H} 1 \mathrm{~N} 1$ virus, but also most importantly the efficiency of transmission. ${ }^{23}$

Influenza H1N1 viruses were introduced to humans and swine around the same time and evolved independently in each host. Analyzing 154 full-length swine H1 HA sequences (classical swine, human-like, and avian-like) shows the predominance at the RBS of the D190 G225 phenotype, with only $25 \%$ of the strains presenting the D190 D225 sequence. In contrast, the analysis of 451 full-length human H1 HA sequences shows the predominance of the D190 D225 phenotype, with some strains having the D190 G225 sequence, corresponding to those viruses from the 40s and 50s right at the end of the H1N1 era, or from the 70s when the H1N1 virus was reintroduced to humans (Table 1). Thus, it is generally the case that D225 paired with D190 is required for efficient human-to-human transmission. Indeed, the ferret transmission studies indicated that viruses with this genotype showed $100 \%$ transmission, whereas viruses with G225 (Table 1) only transmitted to one in three exposed animals. ${ }^{15,22,23}$

Differences in receptor usage by avian and human viruses indicate that AIV do not transmit between humans; therefore, this raised the hypothesis of an intermediate host, likely the pig, in the generation of true pandemic viruses. ${ }^{24}$ This hypothesis is supported by the presence of both SA $\alpha 2,3$ and $\mathrm{SA} \alpha 2,6$ linkages in pig trachea. ${ }^{25}$ Viruses of swine origin infecting humans had a dual pattern of binding for the SA $\alpha 2,3$ and SA 2 2, 6 glycans. ${ }^{16}$ These viruses differ between them by a residue in position $\mathrm{N} 225$ or $\mathrm{G}$. In contrast, seasonal viruses of the H1 subtype showed two differences at residues D225 and $227 \mathrm{~A} \rightarrow \mathrm{E}$ and affinity only for glycans with SA $\alpha 2,6$ linkages when analyzed using the glycan array.

The $H A$ gene of the 2009 pandemic influenza H1N1 virus has its origin from the classical swine lineage. After emergence in the human population, classical swine viruses isolated from American pigs between 1945 and 2009 from the $\alpha, \beta$, and $\gamma$ antigenic groups, as well as swine viruses isolated in the same year as H1N1pdm09 were analyzed in search of those amino acid changes at the RBS required for the novel 2009 virus to transmit to humans. Swine viruses showed selective binding to SA $\alpha 2,6$ sialosides besides the term of circulation and the host from which they were isolated (humans or swine), suggesting that no adaptation steps were required for the transmission of the novel 2009 virus from pigs to humans. ${ }^{26,27}$

The novel H1N1 virus contained the amino acid sequence D190 D225 at the RBS of the HA. The early pdmH1N1 isolates almost exclusively recognized $\alpha 2,6$-linked SAs. Strikingly, some human isolates of the pandemic influenza $\mathrm{H} 1 \mathrm{~N} 1$ virus possess the sequence $\mathrm{G} 225$, such as $\mathrm{H} 1$ viruses of birds; data from other influenza viruses, such as the highly pathogenic avian H5N1, showed that viruses with the avianlike phenotype at the RBS of the HA may target SA $\alpha 2,3$ that is present in the human lung (non-ciliated bronchiolar cells), resulting in a severe lower respiratory tract infection in the human host. ${ }^{28,29}$

Severe cases of H1N1 2009 virus were characterized by viral pneumonitis, indicating a more prominent role of lower respiratory tract infection for this virus than seen

Table I Residues at the RBS of the HA protein of HINI viruses isolated from humans, avian, or swine

\begin{tabular}{|c|c|c|c|c|c|c|c|c|}
\hline \multirow[t]{2}{*}{ Virus subtype } & \multicolumn{6}{|c|}{ Amino acid } & \multicolumn{2}{|c|}{ SA receptor } \\
\hline & 190 & 222 & 225 & 226 & 227 & 228 & AS $\alpha 2,3$ & $A S \alpha 2,6$ \\
\hline \multicolumn{9}{|l|}{ Subtype HI (1918) } \\
\hline Avian & $\mathrm{E}$ & $\mathrm{K}$ & G & Q & $A$ & G & +++ & - \\
\hline Human & $\mathrm{D}$ & $\mathrm{K}$ & $\mathrm{D}$ & Q & $A$ & G & - & +++ \\
\hline Variant & $\mathrm{D}$ & $\mathrm{L}$ & G & Q & $A$ & G & ++ & ++ \\
\hline Human seasonal HINI & $\mathrm{D}$ & $\mathrm{K}$ & $D / G$ & Q & $E$ & G & $+1-$ & +++ \\
\hline Pandemic HINI/09 & $\mathrm{D}$ & $\mathrm{K}$ & $\mathrm{D}$ & Q & $E$ & G & +++ & +++ \\
\hline Human/swine HINI & $\mathrm{D}$ & $\mathrm{K}$ & $\mathrm{D}$ & Q & $A$ & G & + & +++ \\
\hline Swine HINI ${ }^{a}$ & $\mathrm{D}$ & $\mathrm{K}$ & $G / D$ & Q & $\mathrm{A} / \mathrm{E}$ & G & - & +++ \\
\hline Subtype H7N9 & & & & L & & & +++ & - \\
\hline \multicolumn{9}{|l|}{ Subtype H5 (1997-2009) } \\
\hline Avian & $\mathrm{E}$ & & G & $\mathrm{Q}$ & $S$ & G & +++ & - \\
\hline Human & $\mathrm{E}$ & & G & Q & $\mathrm{s}$ & G & +++ & - \\
\hline
\end{tabular}

Notes: Mutations at the residues 190 and 225 are considered key to the receptor specificity by $\mathrm{HI}$ viruses, for some of them also showed the SA receptor affinity. Avian $\mathrm{H} 5$ amino acid sequence at the same residues showed exclusive preference for the SA 22,3 receptor. For H7N9 AIV, the presence of a human-like residue Q226L does not

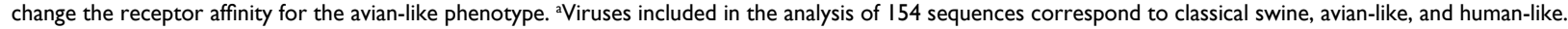
Abbreviations: AIV, avian influenza viruses; HA, hemagglutinin; RBS, receptor-binding site; SA, sialic acid. 
with recently circulating influenza strains. Investigating the binding properties of H1N1pdm09 virus has offered clues on those specific amino acid changes near or at the RBS associated with the dual target of SA $\alpha 2,3$ and $\mathrm{SA} \alpha 2,6$ and the severity of influenza disease. The first marker of pathogenicity and severe clinical outcome has been associated to a single point mutation $\mathrm{D} 225 \mathrm{G}$ at the RBS of the HA, which has been detected in viruses from several countries around the world. ${ }^{30-34}$ Studies using experimental in vivo models analyzing the pathogenic effect of the mutation D225G are controversial; ${ }^{34-37}$ foremost, the amino acid residue 225 has shown polymorphism for $225 \mathrm{D} / \mathrm{G} / \mathrm{N}$ in the $\mathrm{HA}$ of the H1N1pdm09 virus. ${ }^{38,39}$ Overall, viruses with $225 \mathrm{G}$ phenotype showed changes in the virus receptor-binding profile and the cell/tissue tropism and dual binding for SA $\alpha 2,6$ and SA $\alpha 2,3$. On the contrary, viruses with $225 \mathrm{~N}$ showed preference for SA $\alpha 2,6$, though they showed reduced ability to infect human tracheobronchial epithelial cells, an effect that was compensated with a supplementary mutation S185N, expanding their cell tropism, increasing the number of infected cells, and likely, in consequence, the severity of the infection and clinical outcome of the patient. ${ }^{34,36,40,41}$

The evolution of the H1N1pdm09 virus has been followed in detail worldwide; this has been the basis for the selection of vaccine viruses, as well to monitor changes at the antigenic sites, or changes in HA that result in the selection of viruses with better receptor-binding properties. Eight monophyletic groups have been identified based on the sequence variation of the HA1 domain of the $\mathrm{pH} 1 \mathrm{~N} 1$ virus, actually with group 6B.1 being the most represented with viruses from around the globe. ${ }^{42}$ The most frequent amino acid substitutions are contained in the head domain of the HA protein of $\mathrm{pH} 1 \mathrm{~N} 1$. Some mutations such as S206T were acquired soon after the beginning of the pandemic; others, such as A137T, S186P, D100N, S188T, A200T, and S146G, occurred during virus evolution and adaptation, defining the monophyletic groups. These amino acid changes have a direct effect on the receptorbinding properties of the $\mathrm{pH} 1 \mathrm{~N} 1$ viruses and are suggested to have occurred during the evolution and adaptation of the virus as a result of the antigenic drift and the emergence of viral variants that escape from the immune system. ${ }^{43-45}$

\section{Seasonal H3N2 viruses and the progression for differential SAג2,6 linkages}

Human influenza viruses of the H3N2 subtype emerged in the human population during the 1968 pandemic and remain in circulation today. Early during the pandemic, viruses isolated from humans showed acquisition of the mutations Q226L and G228S, which made the virus highly transmissible between humans. The effects of these mutations in viruses of the $\mathrm{H} 3$ subtype demonstrate how the avian precursor of the 1968 human pandemic (A/duck/Ukraine/1/1963) exclusively recognized $\mathrm{SA} \alpha 2,3$, whereas a humanized $\mathrm{H} 3$ virus represented by the $\mathrm{A} /$ Victoria/3/75 strain recognized not only $\mathrm{SA} \alpha 2,6$ but also SA $\alpha 2,3$. More recent $\mathrm{H} 3$ influenza viruses represented by A/Panama/2007/1999 showed a complete switch in its affinity for the $\mathrm{SA}$ receptor, with exclusive recognition of SA $\alpha 2,6$ linkages (Figure 3). The transition between an avian $\mathrm{H} 3$ virus toward a humanized $\mathrm{H} 3$ virus and the effect of mutations 226 and 228 in HA were also observed in human airway epithelium, where avian viruses possessed a restricted infection of ciliated cells in human airway epithelial cell cultures, whereas more recent human $\mathrm{H} 3$ viruses primarily infected non-ciliated cells. ${ }^{18}$

Human influenza H3N2 viruses represent the best example of adaptability and evolution in humans. In consequence, the $\mathrm{H} 3$ virus has presented along those years high antigenic and genetic variability affecting the vaccine efficacy and the need to update the vaccine composition. Major antigenic changes during $\mathrm{H} 3$ evolution occurred in the HA in amino acid positions immediately adjacent to the RBS, substantially changing the virus antibody recognition. ${ }^{46,47}$

Generally, characterization of human H3N2 viruses for vaccine selection is through the agglutination of chicken RBC. ${ }^{18}$ However, antigenic and genetic changes over time have caused a progressive change in the affinity and avidity of $\mathrm{H} 3$ viruses for SA receptors. Initial observations showed that viruses isolated between 1997 and 2005 lost affinity for $\mathrm{SA}$ receptors recognized in chicken $\mathrm{RBCs}$, and that several substitutions at residues E190D or Q226L $\rightarrow \mathrm{I} \rightarrow \mathrm{V}$ or $\mathrm{G} 225 \mathrm{D}$ and W222R, or D225N and S193F accompanied the loss of hemagglutination. ${ }^{20,21,48} \mathrm{~A}$ comprehensive analysis using an array of glycans clearly identified that $\mathrm{H} 3$ evolution during six decades has progressively changed the type of glycan recognized. Early human $\mathrm{H} 3$ viruses had preference for short-branched glycans containing NeuAca2,6 structures. A transition to recognize glycans containing longer branches and linear structures containing $N$-acetyllactosamine (LacNAc) repeats occurred in viruses from the second and third decades. By the years 1998-2008, viruses had lost affinity for binding short glycans and gained affinity for long linear NeuAca2,6(LacNAc) structures. $^{49}$ A recent expansion of these observations analyzed the evolution of human $\mathrm{H} 3$ viruses through different SA $\alpha 2,6$ conformations. A change in binding from single short glycans to branched $\mathrm{N}$ - and 
A

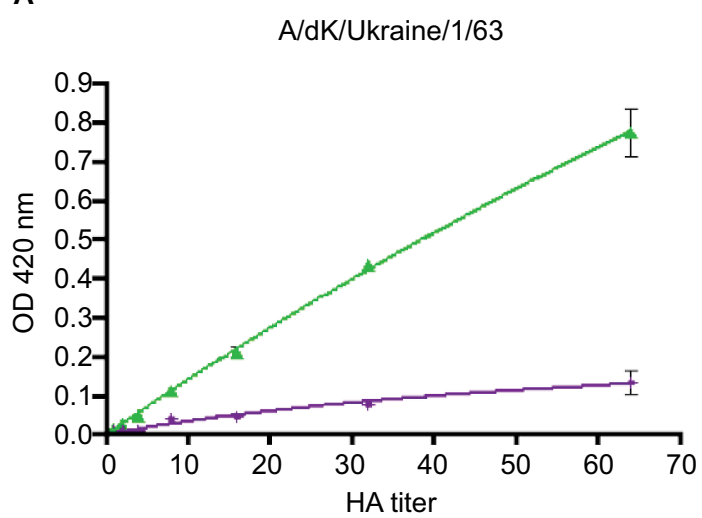

B

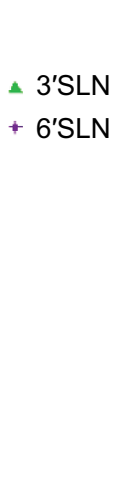

Victoria-wt

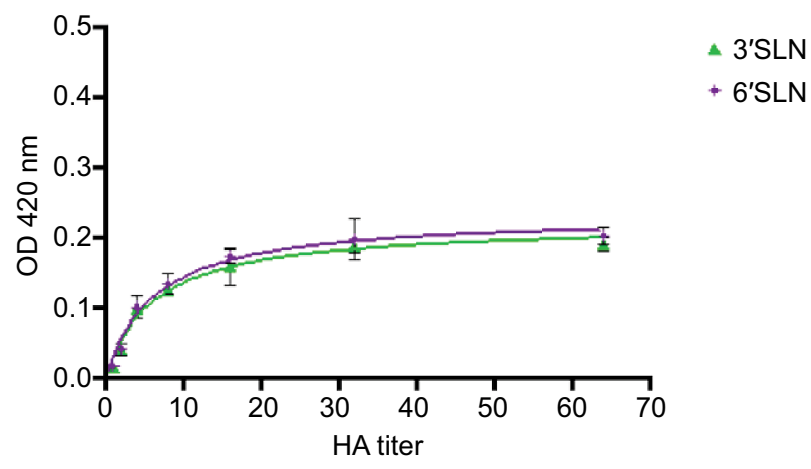

C

A/Panama/2007/99

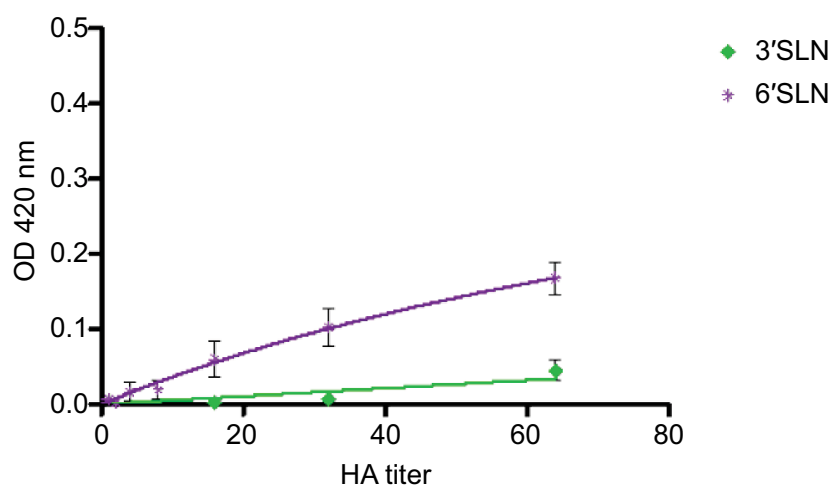

Figure 3 Binding of influenza $\mathrm{H} 3$ viruses representing different stages of the subtype evolution prior to and since its emergence in humans.

Notes: Viruses were analyzed by cross-link binding assay using receptor mimics 3'SLN and 6'SLN. Virus binding to polymers was detected with virus subtype-specific antiserum. ${ }^{64}$ (A) Binding of an AIV (H3N8) to synthetic polymers. The virus shows preference for 3'SLN. (B) Binding of early human IAV (H3N2) to synthetic polymers. The virus shows dual preference for $3^{\prime} \mathrm{SLN}$ and 6'SLN. (C) More recent human $\mathrm{H} 3 \mathrm{~N} 2$ viruses switch the receptor preference for 6'SLN and reduced affinity for the avian-like polymers 3'SLN.

Abbreviations: 3'SLN, 3'-sialyl- $N$-acetyllactosamine trisaccharide; 6'SLN, 6'-sialyl- $N$-acetyllactosamine; HA, hemagglutinin.

O-glycans with three or more LacNac repeats has been attributed to the loss of affinity for chicken RBCs. This study has proposed a bidentate binding model, where these human-type receptors with elongated branches bind to two subunits of the same HA, increasing the avidity of recent $\mathrm{H} 3$ viruses for the complex forms of human SA $\alpha 2,6$ receptors. ${ }^{50}$

The effect of receptor-binding variations in human $\mathrm{H} 3$ viruses through all these years has represented a scientific challenge for virus isolation, antigenic characterization, and vaccine strain selection. A transition in in vitro systems has required moving from only chicken to a broad source as turkey, guinea pig, or human RBCs, without any success. Thus, virus neutralization assays are now more commonly used in addition to hemagglutination inhibition assays to characterize antigenicity and antibody responses. ${ }^{51}$

\section{Avian viruses: $\mathrm{H} 5 \mathrm{NI}$ and $\mathrm{H7Nx}$}

Perhaps the most extensive study on the glycobiology of influenza virus has been done in AIV as a strategy to gain knowledge on the receptor-binding properties of these viruses that might acquire human-to-human transmission properties. In general, AIV, including those that are highly pathogenic in birds, do not replicate efficiently or cause disease in humans. Prior to the influenza virus H5N1 isolated in Hong Kong in 1997, the only reported natural infections in humans by avian viruses are two cases of conjunctivitis associated with avian $\mathrm{H} 7$ viruses, one of which was an infection with a seal virus of avian origin. ${ }^{52,53}$

While influenza's primary site of infection in humans is the upper respiratory tract, the primary infection site in birds is their digestive tract. In contrast to human upper airways, avian guts predominantly express $\mathrm{SA} \alpha 2,3$ receptors. Studies on viruses isolated early during human pandemics, when the $H A$ gene has only just crossed over from an avian source, clearly demonstrate these differences. Sequence analysis of viruses isolated early during the pandemic of 1957 and 1968 revealed that changes at conserved residues of the RBS were associated with human adaptation. Early H2N2 
viruses isolated from humans in 1957 possessed avian-like amino acids Q226 G228 (H3 numbering) at the HA RBS; in vitro assays showed high affinity to the SA $\alpha 2,3$-linked ligand. However, soon after its introduction in humans, the virus acquired a single amino acid change at $226 \mathrm{Q} \rightarrow \mathrm{L}$ and the receptor specificity of these viruses changed toward SA $\alpha 2,6$ binding. A complete human adaptation step occurred when the virus also mutated at the second position Q226L G228S. ${ }^{1,8,54}$ A similar adaptation process occurred for H3 viruses from the 1968 pandemic, once the virus was fully adapted to transmit efficiently between humans. ${ }^{8}$

\section{$\mathrm{H} 5 \mathrm{NI}$ viruses}

The human infections caused by $\mathrm{H} 5 \mathrm{~N} 1$ chicken viruses in Hong Kong in 1997 demonstrated for the first time that AIV could infect humans directly without intermediate evolution. H5 viruses isolated between 1997 and 2004 showed 100\% identity in the RBS; however, viruses from early 2005 have several amino acid changes in the HA, some of which are located in the vicinity of the RBS. ${ }^{55}$ Phylogenetic analysis of H5 viruses isolated from humans and chickens since 1997 shows that 10 clades ( $0-9)$ were distributed in different geographic regions of Asia. ${ }^{56}$ Clade 2 became predominant with an extensive intercontinental expansion of the Asian clade 2.3.4.4. ${ }^{57,58}$ The expansion of the A/Goose/Guangdong/1/1996 lineage included outbreaks of H5N8 viruses in China and South Korea in 2014 and the first detection in the American continent, Canada, and USA of a highly pathogenic reassortant $\mathrm{H} 5 \mathrm{~N} 2$ virus. ${ }^{59}$

A novel H5N6 virus emerged in China in 2014 causing human infections; this novel genotype has replaced the H5N1 as the dominant subtype in southern China. These AIV are known to be the only subtype of clade 2.3.4.4 that is able to cross the host species barrier and infect humans with documented exposure to infected poultry ${ }^{60,61}$ Nonetheless, all H5 AIV isolated to date from birds, mammals, or humans show preferential binding to SA $\alpha 2,3$-linked receptors. ${ }^{62-67}$ As described with the recent human $\mathrm{H} 3 \mathrm{~N} 2$ viruses, a progression on the type of SA $\alpha 2,3$-linked receptors recognized by the avian H5 has been observed, resulting from the high rate of antigenic and genetic diversity in $\mathrm{H} 5 \mathrm{~N} 1$ viruses. Mutations K222Q and S227R are predominant in the RBS of virus HAs from the actual clade 2.3.4.4, conferring a change in receptor-binding specificity and preference for fucosylated receptors and limited capacity for replication and transmission in mammals. ${ }^{68,69}$

Interestingly and of relevance to the potential risk to humans, the chances that avian $\mathrm{H} 5 \mathrm{~N} 1$ viruses will give rise to a pandemic have been deeply analyzed. Viruses and the effect of amino acid changes at the RBS have been tested under several in vitro and in vivo systems, and it is generally accepted that a double mutation at residues $226 \mathrm{Q} \rightarrow \mathrm{L}$ and $228 \mathrm{G} \rightarrow \mathrm{S}$ changed the receptor-binding activity of the avian virus to a human phenotype. The single mutation Q226L seems not to play an important role for the switch on receptor recognition by the $\mathrm{H} 5 \mathrm{HA}$, even though it was paramount for the $\mathrm{H} 2 \mathrm{~N} 2$ and $\mathrm{H} 3 \mathrm{~N} 2$ viruses. $^{8}$ Also, although it makes some change to the SA binding, the single mutant G228S by itself does not affect the complete switch. Then, it may be possible that Q226L is the driving force for the intermediate G228R mutate onward to a G228S. ${ }^{70}$

Despite all the knowledge generated in the last 20 years about the H5N1 viruses, it is still unknown why these viruses have not yet become pandemic to humans. The most recent evidence using the ferret model suggested that for the avian H5N1 virus to become transmissible between humans, several mutations at the HA RBS are required, including those previously described in residues 226 and $228 .{ }^{71-73}$ Considering what is already known about the virus and how long it has been circulating in humans, it might be that $\mathrm{H} 5 \mathrm{~N} 1$ viruses are still far away from an evolutionary adaptation in the human host. However, it should be considered that some other internal genes also contribute to host adaptation; for instance, the PB2 gene appears to play a central role in the ability of IAV to replicate in different hosts. The phenotype of efficient replication in mammalian cells seems to result from an amino acid difference at position 627 (amino acid change E627K, lysine in human strains and glutamate in avian viruses). ${ }^{74,75}$

\section{$\mathrm{H} 7 \mathrm{Nx}$ viruses}

Avian influenza infections in humans are not just of $\mathrm{H} 5 \mathrm{~N} 1$ subtype. Avian viruses of the H7N9 subtype have also become a threat to humans. These AIV, which are restricted to China, infected humans for the first time in 2013; since then, a total of 1557 laboratory-confirmed cases of human infections including at least 605 deaths have been reported to the World Health Organization. ${ }^{76}$ Soon, as the H7N9 viruses were first isolated from the humans, the determinants of pathogenicity were analyzed; it is of great relevance that most of the $\mathrm{H} 7 \mathrm{~N} 9$ viruses isolated possessed a genetic marker of human adaptation in the amino acid residue $226 \mathrm{Q} \rightarrow \mathrm{L},{ }^{77}$ which, in pandemic $\mathrm{H} 2$ and $\mathrm{H} 3$ viruses from 1957 to 1968, allowed the virus to transmit between humans. ${ }^{8}$ Infection studies in different animal models, including mice, macaques, and guinea pigs, shed light on the capacity of H7N9 viruses to replicate 
in different tissues of the upper and lower respiratory airways, which is lethal in mice. ${ }^{78,79}$ Important to the pandemic potential that these viruses represent, besides the presence of mutation Q226L, several transmission studies using the ferret model have demonstrated limited transmission by respiratory droplets. ${ }^{78-82}$ Receptor-binding analysis of H7N9 viruses using solid-phase binding assays or the glycan array have shown that only the presence of $226 \mathrm{~L}$ in these viruses is not sufficient for a complete switch from avian SA $\alpha 2,3$ to the human SA $\alpha 2,6$ receptors. ${ }^{83-87}$ However, if the virus acquires additional mutations, V186G/K-K193T-G228S or V186N-N224K-G228S, it has the capacity to recognize and bind to human trachea to the same extent as a human H3 virus and switch the receptor specificity from avian to human type. ${ }^{88,89}$ The evolutive constrains that maintain H7N9 viruses as a threat to human health are still unknown; implementation of extreme surveillance measures and risk assessment tools will alert in the event of a virus capable of crossing the host range barrier.

Not least important these avian viruses of the H7N7 subtype are also a threat to human health. Worldwide, isolated cases or outbreaks of H7N7 have been reported from the Netherlands and Italy. ${ }^{90,91}$ In humans, infections with avian viruses H7N7 are clinically associated to self-limiting conjunctivitis, and no person-to-person transmission has been reported. Experimental work using the ferret animal model showed that $\mathrm{H} 7$ viruses isolated from the American lineage have already acquired the phenotype of human receptor recognition by binding to several SA $\alpha 2,6$-linked glycans and losing affinity for the avian SA $\alpha 2,3$-linked carbohydrates. Moreover, an avian $\mathrm{H} 7 \mathrm{~N} 7$ isolated from an individual with respiratory disease was transmitted to naïve control ferrets only by direct contact. ${ }^{92,93}$ Infection of eye conjunctiva by the avian H7N7 virus correlates with the predominance of SA $\alpha 2,3 .{ }^{94}$

H7N3 viruses are also associated with conjunctivitis when humans are infected. Historically, these viruses have caused human infection in Italy in 2002, in Canada in 2004, and in England in 2006. ${ }^{91,95,96}$ Recently, two human cases of associated conjunctivitis were reported in two Mexican workers during an outbreak of highly pathogenic avian H7N3 in poultry flocks. ${ }^{97}$ The receptor-binding affinity of H7N3 viruses from the Eurasian and North American lineages showed increased binding of SA $\alpha 2,6$ glycans, exhibiting the characteristics of a human influenza virus without losing affinity for the avian SA $\alpha 2,3$ receptor. However, besides the fact that viruses replicate efficiently in the upper and lower respiratory tracts of ferrets including the recent Mexican viruses from 2012 human cases, transmission between the ferrets still occurs only by direct contact. ${ }^{78,92}$

The most recent event of zoonotic infections with influenza viruses of avian origin was reported in companion animals. An AIV of the H7N2 subtype was isolated from a person infected through direct contact with sick domestic cats. Viruses isolated from the person and the cat showed $99.9 \%$ identity, and they were phylogenetically related to H7N2 viruses isolated from poultry in the USA. The glycan array analysis showed in these viruses preference for $\mathrm{SA} \alpha 2,3$ glycans, though there was some affinity for SA $\alpha 2,6$ humanlike receptors. Even though this seems an isolated event of AIV trespassing the human host range, it certainly reminds us the plasticity of the IAV to cross the species barrier. ${ }^{98}$

\section{Concluding remarks}

Bearing in mind the accumulated evidence about $\mathrm{H} 1, \mathrm{H} 2$, and $\mathrm{H} 3$ viruses that caused the pandemics in the 20th and 21 st centuries, it seems very probable that in addition to reassortment, a prerequisite for a pandemic virus is that its HA protein must adapt to bind SA $\alpha 2,6$ rather than $\mathrm{SA} \alpha 2,3$. The human airway epithelium is a complex organ of different cell types and functions, and is also the target by which the influenza viruses gain entry to their hosts and from where they are transmitted onward to a new host. However, binding to the target cell is a limiting step for efficient virus replication in the host, and human influenza viruses are presumably adapted to optimize their interactions with this organ.

Dissecting the receptor-binding phenotype of influenza virus has become a primary task for researchers and world health authorities around the globe. The World Health Organization published a Tool for Influenza Pandemic Risk Assessment for those countries that have experienced human infections with animal influenza viruses. This information can help scientists better understand the risk these viruses pose to human health and can help support development of tools and strategies for prevention and treatment.

\section{Disclosure}

The author reports no conflicts of interest in this work.

\section{References}

1. Nobusawa E, Aoyama T, Kato H, Suzuki Y, Tateno Y, Nakajima K. Comparison of complete amino acid sequences and receptor-binding properties among 13 serotypes of hemagglutinin of influenza $\mathrm{A}$ viruses. Virology. 1991;182(2):475-485.

2. Wiley DC, Skehel JJ. The structure and function of the hemagglutinin membrane glycoprotein of influenza virus. Апnи Rev Biochem. $1981 ; 56: 365-394$ 
3. Matrosovich MN, Gambarayan AS, Teneberg S, et al. Avian influenza A viruses differ from human viruses by recognition of sialyloligosaccharides and ganglosides and by a higher conservation of the HA receptor-binding site. Virology. 1997;233(1):224-234.

4. Varki A, Cummings R, Esko J, Freeze H, Hart G, Marth J. Essentials of Glycobiology. NY, USA: Cold Spring Harbor Laboratory Press; 1999.

5. Couceiro JN, Paulson JC, Baum LG. Influenza virus strains selectively recognize sialyloligosaccarides on human respiratory epithelium, the role of the host cell in selection of hemagglutinin receptor specificity. Virus Res. 1993;29(2):155-165.

6. Costa T, Chaves AJ, Valle R, et al. Distribution patterns of influenza virus receptors and viral attachment patterns in the respiratory and intestinal tracts of seven avian species. Vet Res. 2012;43:28.

7. Thontiravong A, Kitikoon P, Wannaratana S, et al. Quail as a potential mixing vessel for the generation of new reassortant influenza A viruses. Vet Microbiol. 2012;160(3-4):305-313.

8. Matrosovich M, Tuzikov A, Bovin N, et al. Early alterations of the receptor-binding properties of $\mathrm{H} 1, \mathrm{H} 2$ and $\mathrm{H} 3$ avian influenza virus hemagglutinins after their introduction into mammals. $J$ Virol. 2000;74(18):8502-8512.

9. Ito T, Suzuki Y, Mitnaul L, Vines A, Kida H, Kawaoka Y. Receptor specificity of influenza A viruses correlates with the agglutination of erythrocytes from different animal species. Virology. 1997;227(2): 493-499.

10. Baum LG, Paulson JC. Sialyloligosaccarides of the respiratory epithelium in the selection of human influenza virus receptor specificity. Acta Histochem Suppl. 1990;40:35-38.

11. Gambarayan AS, Robertson JS, Matrosovich MN. Effects of eggadaptation on the receptor binding properties of human influenza A and B viruses. Virology. 1999;258(2):232-239.

12. Mochalova L, Gambarayan A, Romanova J, et al. Receptor-binding properties of modern human influenza viruses primarily isolated in Vero and MDCK cells and chicken embryionated eggs. Virology. 2003;313(2):473-480.

13. Paulson JC, Blixt O, Collins BE. Sweet spots in functional glycomics. Nat Chem Biol. 2006;2(5):238-248.

14. Blixt O, Head S, Mondala T, et al. Printed covalent glycan array for ligand profiling of diverse glycan binding proteins. Proc Natl Acad Sci US A. 2004;101(49):17033-17038.

15. Stevens J, Blixt O, Glaser L, et al. Glycan microarray analysis of the hemagglutinins from modern and pandemic influenza viruses reveals different receptor specificities. J Mol Biol. 2006;355(5):1143-1155.

16. Childs RA, Palma AS, Wharton S, et al. Receptor-binding specificity of pandemic influenza A (H1N1) 2009 virus determined by carbohydrate microarray. Nat Biotechnol. 2009;27(9):797-799.

17. Matrosovich MN, Matrosovich TY, Gray T, Roberts NA, Klenk HD. Human and avian influenza viruses target different cell types in cultures of human airway epithelium. Proc Natl Acad Sci U S A. 2004;101(13):4620-4624.

18. Thompson C, Barclay WS, Zambon MC, Pickles RJ. Infection of human airway epithelium by human and avian strains of influenza A virus. J Virol. 2006;80(16):8060-8068.

19. Yamada S, Suzuki Y, Suzuki T, et al. Haemagglutinin mutations responsible for the binding of $\mathrm{H} 5 \mathrm{~N} 1$ influenza A viruses to human-type receptors. Nature. 2006;444(7117):378-382.

20. Medeiros R, Escriou N, Naffakh N, Manuguerra JC, van der Werf S. Hemagglutinin residues of recent human $\mathrm{A}(\mathrm{H} 3 \mathrm{~N} 2)$ influenza viruses that contribute to the inability to agglutinate chicken erythrocytes. Virology. 2001;289(1):74-85.

21. Nobusawa E, Ishihara H. Morishita T, Sato K, Nakajima K. Change in receptor-binding specificity of recent human influenza $\mathrm{A}$ viruses (H3N2): a single amino acid change in hemagglutinin altered its recognition of sialyloligosaccharides. Virology. 2000;278(2): $587-596$

22. Glaser L, Stevens J, Zamarin D, et al. A single amino acid substitution in 1918 influenza virus hemagglutinin changes receptor binding specificity. J Virol. 2005;79(17):11533-11536.
23. Tumpey TM, Maines TR, Van Hoeven N, et al. A two-amino acid change in the hemagglutinin of the 1918 influenza virus abolishes transmission. Science. 2007;315(5812):655-659.

24. Scholtissek C. Source for influenza pandemics. Eur J Epidemiol. 1994; 10:455-458.

25. Ito T, Couceiro JN, Kelm S, et al. Molecular basis for the generation in pigs of influenza A viruses with pandemic potential. $J$ Virol. 1998;72(9):7367-7373.

26. Bradley KC, Jones CA, Tompkins SM, et al. Comparison of the receptor binding properties of contemporary swine isolates and early human pandemic H1N1 isolates (Novel 2009 H1N1). Virology. 2011;413(2):169-182.

27. Chen LM, Rivailler P, Hossain J, et al. Receptor specificity of subtype $\mathrm{H} 1$ influenza A viruses isolated from swine and humans in the United States. Virology. 2011;412(2):401-410.

28. Shinya K, Ebina M, Yamada S, Ono M, Kasai N, Kawaoka Y. Influenza virus receptors in the human airway. Nature. 2006;440(7083):435-436.

29. Shinya K, Hatta M, Yamada S, et al. Characterization of a human H5N1 influenza A virus isolated in 2003. J Virol. 2005;79(15):9926-9932.

30. Chen H, Wen X, To KK, et al. Quasispecies of the D225G substitution in the hemagglutinin of pandemic influenza A(H1N1) 2009 virus from patients with severe disease in Hong Kong, China. J Infect Dis. 2010;201(10):1517-1521.

31. Moussi AE, Kacem MA, Pozo F, et al. Frequency of D222G haemagglutinin mutant of pandemic (H1N1) pdm09 influenza virus in Tunisia between 2009 and 2011. Diagn Pathol. 2013;8:124.

32. Ledesma J, Pozoa F, Pérez Ruiz M, et al. Substitutions in position 222 of haemagglutinin of pandemic influenza A (H1N1) 2009 viruses in Spain. J Clin Virol. 2011;51(1):75-78.

33. Rykkvin R, Kilander A, Dudman SG, Hungnes O. Within-patient emergence of the influenza $\mathrm{A}(\mathrm{H} 1 \mathrm{~N} 1)$ pdm09 HA1 222G variant and clear association with severe disease, Norway. Euro Surveill. 2013;18(3):20369.

34. Vazquez-Perez JA, Isa P, Kobasa D, et al. A (H1N1) pdm09 HA D222 variants associated with severity and mortality in patients during a second wave in Mexico. Virol J. 2013;10:41.

35. Abed Y, Pizzorno A, Hamelin ME, et al. The 2009 pandemic H1N1 D222G hemagglutinin mutation alters receptor specificity and increases virulence in mice but not in ferrets. J Infect Dis. 2011;204(7):1008-1016.

36. Casalegno JS, Ferraris O, Escuret V, et al. Functional balance between the hemagglutinin and neuraminidase of influenza A(H1N1)pdm09 HA D222 variants. PLos One. 2014;9(8):e104009.

37. Chutinimitkul S, Herfst S, Steel J, et al. Virulence-associated substitution D222G in the hemagglutinin of 2009 pandemic influenza A(H1N1) virus affects receptor binding. J Virol. 2010;84(22):11802-22813.

38. Baldanti F, Campanini G, Piralla A, et al. Severe outcome of influenza A/H1N1/09v infection associated with $222 \mathrm{G} / \mathrm{N}$ polymorphisms in the haemagglutinin: a multicentre study. Clin Microbiol Infect. 2011;17(8):1166-1169.

39. Resende PC, Motta FC, Oliveira MLA, et al. Polymorphisms at residue 222 of the hemagglutinin of pandemic influenza $\mathrm{A}(\mathrm{H} 1 \mathrm{~N} 1)$ pdm09: association of quasispecies to morbidity and mortality in different risk categories. PLos One. 2014;9(3):e92789.

40. Houng HS, Garner J, Zhou Y, et al. Emergent 2009 influenza A(H1N1) viruses containing HA D222N mutation associated with severe clinical outcomes in the Americas. J Clin Virol. 2012;53(1):12-15.

41. Matos-Patrón A, Byrd-Leotis L, Steinhauer DA, Barclay WS, AyoraTalavera G. Amino acid substitution D222N from fatal influenza infections affects receptor-binding properties of the influenza A(H1N1) pdm09 virus. Virology. 2015;484:15-21.

42. McCauley J, Daniels R, Lin YP, Xiang Z, Gregory V, Whittaker L. Report Prepared for the WHO Annual Consultation on the Composition of Influenza Vaccine for the Northern Hemisphere 2016-2017. World Health Organization: Place, Geneva, Switzerland; 2016.

43. de Vries RP, de Vries E, Martínez-Romero C, et al. Evolution of the hemagglutinin protein of the new pandemic H1N1 influenza virus: maintaining optimal receptor binding by compensatory substitutions. J Virol. 2013;87(24):13868-13877. 
44. Hensley SE, Das SR, Bailey AL, et al. Hemagglutinin receptor binding avidity drives influenza A virus antigenic drift. Science. 2009;326(5953):734-736.

45. Koel BF, Mögling R, Chutinimitkul S, et al. Identification of amino acid substitutions supporting antigenic change in influenza $A(H 1 N 1)$ pdm09 viruses. J Virol. 2015;89(7):3763-3775.

46. Koel BF, Burke DF, Bestebroer TM, et al. Substitutions near the receptor binding site determine major antigenic change during influenza virus evolution. Science. 2013;342(6161):976-979.

47. Smith DJ, Lapedes AS, de Jong JC, et al. Mapping the antigenic and genetic evolution of influenza virus. Science. 2004;305(5682):371-376.

48. Lin YP, Xiong $X$, Wharton SA, et al. Evolution of the receptor binding properties of the influenza A(H3N2) hemagglutinin. Proc Natl Acad Sci U S A. 2012;109(52):21474-21479.

49. Gulati S, Smith DF, Cummings RD, et al. Human H3N2 influenza viruses isolated from 1968 to 2012 show varying preference for receptor substructures with no apparent consequences for disease or spread. PLos One. 2013;8(6):e66325.

50. Peng W, de Vries RP, Grant OC, et al. Recent H3N2 viruses have evolved specificity for extended, branched huma-type receptors, confering potential for increased avidity. Cell Host Microbe. 2017;21(1): 23-34.

51. Ampofo WK, Al Busaidy S, Cox NJ, et al; WHO Writing Group. Strengthening the influenza vaccine virus selection and development process: outcome of the 2nd WHO informal consultation for improving influenza vaccine virus selection held at the Centre International de Conférences (CICG) Geneva, Switzerland, 7 to 9 December 2011. Vaccine. 2013;31(32):3209-3221.

52. Kurtz J, Manvell RJ, Banks J. Avian influenza virus isolated from a woman with conjunctivitis. Lancet. 1996;348(9031):901-902.

53. Webster RG, Geraci J, Petursson G, Skirnisson K. Conjunctivitis in human beings caused by influenza A virus of seals. $N$ Engl $J$ Med. 1981;304(15):911.

54. Connor RJ, Kawaoka Y, Webster RG, Paulson JC. Receptor specificity in human, avian, and equine $\mathrm{H} 2$ and $\mathrm{H} 3$ influenza virus isolates. Virology. 1994;205(1):17-23.

55. WHO. Evolution of $\mathrm{H} 5 \mathrm{~N} 1$ avian influenza viruses in Asia. Global influenza program surveillance network. Emerg Infect Dis. 2005;11(10):1515-1521.

56. WHO/OIE/FAO H5N1 Evolution Working Group. Toward a unified nomenclature system for highly pathogenic avian influenza virus (H5N1). Emerg Infect Dis. 2008;14(7):e1.

57. de Vries E, Guo H, Dai M, Rottier PJ, van Kuppeveld FJ, de Haan CA. Rapid emergence of highly pathogenic avian influenza subtypes from a subtype H5N1 hemagglutinin variant. Emerg Infect Dis. 2015;21(5):842-846.

58. Saito T, Tanikawa T, Uchida Y, Takemae N, Kanehira K, Tsunekuni R. Intracontinental and intercontinental dissemination of Asian H5 highly pathogenic avian influenza virus (clade 2.3.4.4) in the winter of 2014-2015. Rev Med Virol. 2015;25(6):388-405.

59. Ip HS, Torchetti MK, Crespo R, et al. Novel Eurasian highly pathogenic avian influenza A H5 viruses in wild birds, Washington, USA, 2014. Emerg Infect Dis. 2015;21(5):886-890.

60. Bi Y, Chen Q, Wang Q, et al. Genesis, evolution and prevalence of H5N6 avian influenza viruses in China. Cell Host Microbe. 2016;20(6):810-821.

61. Herfst S, Mok CKP, van den Brans JMA, et al. Human clade 2.3.4.4 A/H5N6 influenza virus lacks mammalian adaptation markers and does not transmit via the airborne route between ferrets. mSphere. 2018;3(1):e00405-e00417.

62. Gambarayan AS, Tuzikov AB, Pazynina GV, Webster RG, Matrosovich $\mathrm{MN}$, Bovin NV. H5N1 chicken influenza viruses display a high binding affinity for Neu5Aca2-3GalB1-4(6-HS03)GlcNac-containing receptors. Virology. 2004;326(2):310-316.

63. Gambarayan A, Tuzikov A, Pazynina G, Bovin N, Balish A, Klimov A. Evolution of the receptor binding phenotype of influenza A(H5) viruses. Virology. 2006;344(2):432-438.
64. Ha Y, Stevens DJ, Skehel JJ, Wiley DC. X-ray structures of H5 avian and $\mathrm{H} 9$ swine influenza virus hemagglutinin bound to avian and human receptor analogs. Proc Natl Acad Sci U SA. 2001;98(20):11181-11186.

65. Iwatsuki-Horimoto K, Kanazawa R, Sugii S, Kawaoka Y, Horimoto T. The index influenza A virus subtype $\mathrm{H} 5 \mathrm{~N} 1$ isolated from a human in 1997 differs in its receptor-binding properties from a virulent avian influenza virus. J Gen Virol. 2004;85(Pt 4):1001-1005.

66. Matrosovich M, Zhou N, Kawaoka Y, Webster R. The surface glycoprotein of $\mathrm{H} 5$ influenza viruses isolated from humans, chickens, and wild aquatic birds have distinguishable properties. $J$ Virol. 1999;73(2):1146-1155.

67. Puthavathana P, Auewarakul P, Charoenying PC, et al. Molecular characterization of the complete genome of human influenza H5N1 virus isolated from Thailand. $J$ Gen Virol. 2005;86(Pt 2):423-433.

68. Guo H, de Vries E, McBride R, et al. Highly pathogenic influenza $\mathrm{A}(\mathrm{H} 5 \mathrm{Nx})$ viruses with altered $\mathrm{H} 5$ receptor-binding specificity. Emerg Infect Dis. 2017;23(2):220-231

69. Kaplan BS, Russier M, Jeevan T, et al. Novel highly pathogenic avian $\mathrm{A}(\mathrm{H} 5 \mathrm{~N} 2)$ and $\mathrm{A}(\mathrm{H} 5 \mathrm{~N} 8)$ influenza viruses of clade 2.3.4.4 from North America have limited capacity for replication and transmission in mammals. mSphere. 2016;1(2): $000003-\mathrm{e} 00016$.

70. Ayora-Talavera G, Shelton H, Scull MA, et al. Mutations in H5N1 influenza virus hemagglutinin that confer binding to human tracheal airway epithelium. PLos One. 2009;4(11):e7836.

71. Xiong X, Tuzikov A, Coombs PJ, et al. Recognition of sulphated and fucosylated receptor sialosides by A/Vietnam/1194/2004 (H5N1) influenza virus. Virus Res. 2013;178(1):12-14.

72. Herfst S, Schrauwen EJ, Linster M, et al. Airborne transmission of influenza A/H5N1 virus between ferrets. Science. 2012;336(6088):1534-1541.

73. Imai M, Watanabe T, Hatta M, et al. Experimental adaptation of an influenza H5 HA confers respiratory droplet transmission to a reassortant H5 HA/H1N1 virus in ferrets. Nature. 2012;486(7403):420-428.

74. Hatta M, Gao P, Halfmann P, Kawaoka Y. Molecular basis for high virulence of Hong Kong H5N1 inluenza A viruses. Science. 2001;293(5536):1840-1842.

75. Subbarao EK, London W, Murphy BR. A single amino acid in the PB2 gene of influenza A virus is a determinant of host range. $J$ Virol. 1993;67(4):1761-1764.

76. WHO. Influenza at the Human-Animal Interface. Summary and Assessment, 16 June 2017 to 25 July 2017. World Health Organization: Place, Geneva, Switzerland; 2017.

77. Gao R, Cao B, Hu Y, et al. Human infection with a novel avian-origin influenza A (H7N9) virus. N Engl J Med. 2013;368(20):1888-1897.

78. Belser JA Gustin K, Pearce MB, et al. Pathogenesis and transmission of avian influenza A (H7N9) virus in ferrets and mice. Nature. 2013;501(7468):556-559.

79. Watanabe T, Kiso M, Fukuyama S, et al. Characterization of H7N9 influenza A viruses isolated from humans. Nature. 2013;501(7468):551-555.

80. Richard M, Schrauwen EJ, de Graaf M, et al. Limited airborne transmission of H7N9 influenza A virus between ferrets. Nature. 2013;501(7468):560-563.

81. Xu L, Bao L, Deng W, et al. Novel avian-origin human influenza $\mathrm{A}(\mathrm{H} 7 \mathrm{~N} 9)$ can be transmitted between ferrets via respiratory droplets. J Infect Dis. 2014;209(4):551-556.

82. Zhang Q Shi J, Deng G, et al. H7N9 influenza viruses are transmissible in ferrets by respiratory droplet. Science. 2013;341(6144):410-414.

83. Dormant JC, Dekkers J, Wickramasinghe IN, et al. Adaptation of novel H7N9 influenza A virus to human receptors. Sci Rep. 2013;3:3058.

84. Schrauwen EJ, Richard M, Burke DF, Rimmelzwaan GF, Herfst S, Fouchier RA. Amino acid substitutions that affect receptor binding and stability of the hemagglutinin of influenza A/H7N9 virus. $J$ Virol. 2016;90(7):3794-3799.

85. Shi Y, Zhang W, Wang F, et al. Structures and Receptor binding of hemagglutinins from human-infecting H7N9 influenza viruses. Science. 2013;342(6155):243-247

86. Xiong X, Martin SR, Haire LF, et al. Receptor binding by an H7N9 influenza virus from humans. Nature. 2013;499(7459):496-499. 
87. Xu R, de Vries RP, Zhu X, et al. Preferential recognition of avianlike receptors in human influenza A H7N9 viruses. Science. 2013;342(6163):1230-1235.

88. Tharakaraman K, Jayaraman A, Raman R, et al. Glycan receptor binding of the influenza A virus H7N9 hemagglutinin. Cell. 2013;153(7):1486-1493.

89. de Vries RP, Peng W, Grant OC, et al. Three mutations switch H7N9 influenza to human-type receptor specificity. PLoS Pathog. 2017;13(6):e1006390.

90. Fouchier RA, Schneeberger PM, Rozendaal FW, et al. Avian influenza A virus (H7N7) associated with human conjunctivitis and a fatal case of acute respiratory distress syndrome. Proc Natl Acad Sci U S A. 2004;101(5):1356-1361.

91. Puzelli S, Di Trani L, Fabiani C, et al. Serological analysis of serum samples from humans exposed to avian $\mathrm{H} 7$ influenza viruses in Italy between 1999 and 2003. J Infect Dis. 2005;192(8):1318-1322.

92. Belser JA, Blixt O, Chen LM, et al. Contemporary North American influenza $\mathrm{H} 7$ viruses possess human receptor specificity: implications for virus transmissibility. Proc Natl Acad Sci U S A. 2008;105(21):7558-7563.
93. Belser JA, Creager H, Zeng H, Maines TR, Tumpey TM. Pathogenesis, transmissibility, and tropism of a highly pathogenic avian influenza $\mathrm{A}(\mathrm{H} 7 \mathrm{~N} 7)$ virus associated with human conjunctivits in Italy, 2013. $J$ Infect Dis. 2017;216(Suppl 4):S508-S511.

94. Olofsson S, Kumlin U, Dimock K, Arnberg N. Avian influenza and sialic acid receptors: more than meets the eye? Lancet Infect Dis. 2005;5(3):184-188.

95. Tweed SA, Skowronski DM, David ST, et al. Human illness from avian influenza H7N3, British Columbia. Emerg Infect Dis 2004;10(12):2196-2199.

96. Nguyen-Van-Tam JS, Nair P, Acheson P, et al; Incident Response Team. Outbreak of low pathogenicity H7N3 avian influenza in UK, including associated case of human conjunctivitis. Euro Surveill. 2006;11(5):E060504.

97. Lopez-Martinez I, Balish A, Barrera-Badillo G, et al. Highly pathogenic avian influenza $\mathrm{A}(\mathrm{H} 7 \mathrm{~N} 3)$ virus in poultry workers, Mexico, 2012. Emerg Infect Dis. 2013;19(9):1531-1534.

98. Marinova-Petkova A, Laplante J, Jang Y, et al. Avian influenza A(H7N2) virus in human exposed to sick cats, New York, USA, 2016. Emerg Infect Dis. 2017;23(12):2046-2049.

\section{Publish your work in this journal}

The Journal of Receptor, Ligand and Channel Research is an international peer reviewed, open access, online journal. The journal welcomes laboratory and clinical findings in the fields of biological receptors, ligands, channel and signal transduction research including: receptors and signalling; ligands; transporters, pores and channels; binding and activation; receptor

\section{Dovepress}

regulation; role of receptors in diseases and their treatment; molecular basis of membrane structure and functions; molecular models of membranes. The manuscript management system is completely online and includes a very quick and fair peer-review system. Visit http://www.dovepress.com/ testimonials.php to read real quotes from published authors. 